Island Studies Journal, Vol. 11, No. 2, 2016, pp. 343-358

\title{
Mapping the Outer Hebrides in sound: towards a sonic methodology
}

\author{
Cathy Lane \\ University of the Arts \\ London, United Kingdom \\ c.lane@lcc.arts.ac.uk
}

\begin{abstract}
Scottish Gaelic is still widely spoken in the Outer Hebrides, remote islands off the West Coast of Scotland, and the islands have a rich and distinctive cultural identity, as well as a complex history of settlement and migrations. Almost every geographical feature on the islands has a name which reflects this history and culture. This paper discusses research which uses sound and listening to investigate the relationship of the islands' inhabitants, young and old, to placenames and the resonant histories which are enshrined in them and reveals them, in their spoken form, as dynamic mnemonics for complex webs of memories. I speculate on why this 'place-speech' might have arisen from specific aspects of Hebridean history and culture and how sound can offer a new way of understanding the relationship between people and island toponymies.
\end{abstract}

Keywords: Gaelic, island, landscape, memory, Outer Hebrides, place-speech, sound

(C) 2016 - Institute of Island Studies, University of Prince Edward Island, Canada

\section{Introduction}

I am a composer, sound artist and academic. In my creative practice I compose concert works and gallery installations. My current practice focuses around sound-based investigations of a place or theme and uses a mixture of field recording, interview, spoken text and existing oral history archive recordings as material. I am interested in the semantic and the abstract sonic qualities of all this material and I use it to construct "docu-music" (Lane, 2006).

The Outer Hebrides, remote islands off the west coast of Scotland have been one of the major focuses of my work for the last decade and my relationship with the islands predates that. A number of individual compositions, many of which have received public performances and exhibitions have been released on a CD entitled The Hebrides Suite (Lane, 2013) and I have talked and written about the work in a number of different forums. ${ }^{1}$

The sound art project, which forms the focus of this paper, took place in 2015 on the islands of South and North Uist and Benbecula, Outer Hebrides, Scotland. Working through sound and listening as a medium of interrogation and using recorded sound as material for composition, the project aimed to interrogate the 'resonances' of placenames and how they "transcribe or fix" memories and historical events onto a landscape. It also investigated intergenerational relationships to placenames through the medium of sound, primarily oral history recordings old and new. Underpinning this research were questions about whose history could be commemorated on the landscape with the aim of anecdotally renaming some of these places according to other histories and other memories, both shared and individual. The

\footnotetext{
${ }^{1}$ For a full list see http://hebrides-suite.co.uk
} 
project resulted in the sound composition 'Sandy Jaffas', which along with other works from The Hebrides Suite was exhibited in the gallery at Museum nan Eilean, Lionacleit, Benbecula for three months in 2015.

Home, kinship and belonging emerged as key themes in the research, revealing mentalmaps where individual and collective memories are being constantly per-formed and reformed into new relationships and understandings of the links between the past and the present. In this paper, I interrogate placenames, not as static written forms but as dynamic soundings which, between Gaelic speaking inhabitants of the Outer Hebrides, in particular, act as a sounding 'node' or mnemonic for past, present, personal and collective memories. I call on scholarly studies from a number of disciplines, particularly memory (Baddeley, 1999; Rose, 2003; Yates, 1992); sound (Dyson, 2014; Voegelin, 2014); performance (Heddon, 2008) and landscape (Chatwin, 1987; Lippard, 1997; MacFarlane, 2015; Spirn, 2008) as well as literature about the Outer Hebrides. I investigate the significance of the spoken placename with reference to three aspects of Hebridean culture: land use, language and oral tradition. I also speculate on how sonic methodology and sound as a means of dissemination might offer new insights and a more nuanced 'listening in' to the relationship between people and island toponymies.

\section{Land use, language and the oral tradition in the Outer Hebrides}

In this section I expand on my previous introduction to the Outer Hebrides (Lane, 2011) to concentrate on the aspects of geography, history and culture that are most relevant to the islands' onomasticon.

The placenames of the Outer Hebrides are a mixture of Norse and Gaelic often with Anglicized equivalents. The names by and large emanate from geographical features and local history. For this paper, however, there are three specific aspects of the social and cultural life of the Outer Hebrides that need expansion.

\section{Crofting, land tenure and relationship to landscape}

"The words 'croft', from the Gaelic 'croit' means a small area of enclosed land." (Stewart, 2005, p.3). In the crofting counties of Northern Scotland such as Shetland, Orkney, Caithness, Sutherland, Ross and Cromarty, Inverness, and Argyll, land was divided into small individual crofts and common land. "It was a close-knit, communal life" (Stewart, 2005, p. 7) which shared the growing and harvesting of crops, and the tending of livestock, including taking the cattle to graze on higher ground every summer. The crofting year revolved round the shared labor (cutting peat, thatching roofs, and shearing and dipping sheep) necessary to sustain life, as well as a shared social life.

The way that the land was used and traversed made it necessary to name every little geographical feature,

Most of the shielings ${ }^{2}$ are several miles, some six or eight some twelve or fourteen miles, from the town land homes. The moorlands are rough and rigged and full of swamps and channels, and the people use much care in guiding the cattle, especially the young ones not yet experienced in travelling (Sinclair, 1996, p. 86).

\footnotetext{
${ }^{2}$ Temporary huts for visiting summer pastures.
} 
The system also meant that people's lives and livelihoods were intimately bound together. During fieldwork many of my older subjects mentioned times when people would come together in places of significance to the community. These communal gatherings are often gender specific, for example, a number of subjects talked about women and children meeting daily for the evening milking on a specific place on the machair, the fertile low-lying grassy plain found on some of the northwest coastlines of Ireland and Scotland, in particular the Outer Hebrides,

Every summer the cattle were taken down to the machair to graze and they had a cowherd employed for the summer. After the cows were milked in the morning they were set out to the common grazing and then the cowherd drove them down to the machair and we had to go down in the evenings - there was a cattle fold on the machair - and we used to go down there with my auntie to milk the cows, and that was a meeting place. That's where they socialized and chatted about the gossip of the village and the area, and we thoroughly enjoyed it." (MacKillop, recorded interview, 2015)

Other gatherings were seasonal, for example, waulking the tweed, the technique of handfinishing newly-woven tweed by soaking it and thumping it rhythmically to shrink and soften it; cutting the peats ${ }^{3}$; thatching roofs; shearing sheep; ploughing etc. The co-incidence of these points of remembrance suggests an individualized yet shared heritage of place and function,

There are no particular features in the township which show a development from feudal bond to freehold: no village square, no village pub to act as a neutral area for local discussion, no visible memorials to the war dead and none of the outward trappings which indicate a closely-knit social community. Yes, the crofting township is a tight social unit, simply because is it the folk of the township who are the dynamic elements; the physical environment is merely a stage setting (Sinclair, 1996, p. 67).

This resonates with landscape scholar Anne Sprin's concept of landscape as a series of,

'performance spaces' ... generated by active processes ... Each kind of performance space is derived from archetypal needs and activities and the means invented to meet or accommodate them. Some needs and activities are basic to survival - moving, finding sustenance, stimulating senses, reproducing, growing, identifying, and controlling and making/building. Others are social - belonging, communicating, trading, playing, learning and conflict (Sprin, 1998, p. 121).

In formal conversation with my subjects, as well as in overheard everyday conversation, I felt that past performances related to place were as important as those in the present. Traditionally crofters had no security of tenure and the precarity of their situation is demonstrated by the history of emigration from the islands. In the past this was caused by a mixture of famine and poverty and successive clearances by landowners to make way for sheep, which at the time were more profitable than people,

\footnotetext{
${ }^{3}$ Peat is formed from partially decayed vegetation or organic matter and found in boggy moorland areas. It is cut (turfed), dried and used for fuel.
} 
In those days there were large families and they had 'croft' but they didn't have security of tenure and sometime two or maybe three families lived on the croft so there were too many, and anyway he (the landlord Lord MacDonald of Sleat) wanted to clear the land to make it into a what we called a 'tack', a small farm and he didn't need those people (MacKillop, recorded interview, 2015).

This has resulted in diasporic Hebridean settlements in Canada, Australia and New Zealand many of which still have strong cultural and family links with the islands. Often my subjects talked about events that happened to their families over a century ago as if they were events that had happened in the previous year and these historical events seemed equally as important as the recent past. "All that the women had to fight with were clods of earth and stones, and of course there was a baton charge and they got their heads bashed in and, well, that little stream its called 'river of blood",4 (MacCuish, recorded interview 2015) Hebridean returners, even if they left the island several generations ago, will discuss their family and where they originally came as they are fitted into a dynamic conceptual map of family, kinship and place. The following quotation from Alasdair MacEachan, talking about the small, now uninhabited island of Wiay off the coast of Benbecula shows the close link between past and present and suggests some of these connections between place, placenames, oral culture, memory and family,

My great grandfather was the last man living in Wiay - Calum MacRae. He got the island from Lady Catherine Cathcart in 1912 and he got a list ${ }^{5}$. Finlay Monk stayed there first, one of Alex Brown's clan. When they left, Calum Macrae got the place, so that is my great grandfather on my father's side. Mary, daughter of Calum MacRae was my grandmother. He stayed there with his wife and family of seven, one of them died young. Then Calum's first wife died in 1920, he married again seven years after that. When he then died himself, his second wife and one of his sons Duncan found life a little difficult and they moved to Rossinish. The house that is in Rossinish today, that is where they were. ... I took him (my uncle Ronald) out to Wiay a few years before he died, and that had been 60 years since he had been out there, and he could still name pretty much all the different parts of the island. He had so many names, I wrote them down (MacEachan, recorded interview, 2015).

Elsewhere in the interview Alasdair reveals slippage between the past and the present when talking about Aird on Benbecula where he lives "that is where the family have (lived) since well, it's been 350 years or so, sometime around Culloden 6 or before ... There's still quite a few of the original families there" (MacEachen, recorded interview, 2015). These two quotations from Alasdair reinforce the idea that "Landscape may be inhabited in imagination" (Spirn, 2008, p. 18) and suggest mental maps of a web of family performances in a landscape that stretches back over time and is closely associated with place. Thus placenames help the

\footnotetext{
${ }^{4}$ Refers to the Battle of Sollas, North Uist, 1848, when the constables were sent to clear the people off the land.

${ }^{5} \mathrm{I}$ am as yet unable to clarify what a 'list' is.

${ }^{6}$ The Battle of Culloden was the final confrontation of the Jacobite rising of 1745 and part of a religious civil war in Britain with the Roman Catholic and Scottish Episcopalian Jacobites fighting the Anglican British government. The defeat of the Jacobites marked the end of the power of the Scottish clan system.
} 
Hebridean to "form mental images of the things they wish to remember and store those images in the places, so that the order of the places will preserve the order of the things" (Cicero in Yates, 1992, p. 17). While these 'sites of performance' relate specifically to crofting communities and their land usage, their resonance is also tied up in language and the nature of Gaelic.

\section{Gaelic language and culture.}

The Outer Hebrides are the most strongly coherent Scottish Gaelic (Gàidhlig) speaking area in the world. ${ }^{7}$ While many of my subjects only spoke Gaelic until they went to school and began learning English, many received Gaelic medium education at school,

Gaelic provides a perceptual grid or cognitive map of reality influencing the social behaviour of its speakers and the social institutions of its speech community (MacKinnon, 1977, p. 27).

This is evidenced by placenames which reflect the Gaelic topocosm as well as the traditional activities of the crofting community for example: cladach, the sea shore; machair, the sandy coastal margins and dune land; talamh-treabhaidh, the mixed black and light soils suitable for arable use; dubhthalamh, the poorer black soils; gearraidh, rough grazing no longer cultivated; and monadh, mountain slopes and moor used for extensive summer pastures only and for peat cutting. Apart from finding their way into numerous placenames (e.g. On North Uist Cladach a'Baile Shear; Cladach Chaolais; Cladach Bhalaigh; Cladach Cairinis; Cladach Circeaboist; Cladach Iolaraigh), these Gaelic words describe an evolutionary dialogue between people and place; between human activity and the land; between society, environment and culture,

Ultra-fine discrimination operates in Hebridean Gaelic place names, as well as in descriptive nouns. In the 1990s an English linguist called Richard Cox moved to northern Lewis ${ }^{8}$, taught himself Gaelic, and spent several years retrieving and recording the place-names in the Carloway district of Lewis's west coast. Carloway contains thirteen townships and around 500 people; it is fewer than sixty square miles in area. But Cox's magnificent resulting work The Gaelic Place-Names of Carloway, Isle of Lewis: Their Structure and Significance (2002) runs to almost 500 pages and details more than 3000 place names. Its eleventh section, titled 'The Ononmasticon', lists the hundreds of toponyms identifying 'natural features' of the landscape. Unsurprisingly for such a maritime culture, there is a proliferation of names for coastal features - narrows, currents, indentations, projections, ledges, reefs - often exceptional specificity ... To speak out a run of these names is therefore to create a story of travel: an act of naming that is also an act of wayfinding (MacFarlane, 2015, pp. 19-20).

\footnotetext{
${ }^{7}$ Gaelic is a Celtic language related to Welsh, Cornish and Breton. In the 1901 and 1921 censuses, all parishes were reported to be over $75 \%$ Gaelic speaking, by 1971 most areas were still more than $75 \%$ Gaelic speaking and it remains a relatively strong in spite of a continued decline. In the 2001 census $61.1 \%$ of the population of the Outer Hebrides spoke Gaelic compared with $1.2 \%$ in the whole of Scotland.

${ }^{8}$ Lewis is the largest and most populated island of the Outer Hebrides.
} 
The Place Names of Uist: A guide to the derivation of some local placenames ${ }^{9}$ compiled for Ian Fraser of the School of Scottish Studies and now incorporated in the Scottish Place-Name Survey, ${ }^{10}$ divides the names into five main sections: island, habitative, topographic settlement, landward elements and coastal elements. This small document suggests both the derivations of the names from Norse or Gaelic and how some may have changed over time according to the dominant colonial power. Unsurprisingly coastal elements is the largest section containing examples such as: 'Nes' a Norse word meaning promontory which in North Uist has given rise to names such as Otternish, Siginish, Suenish, Sponish, Minish, Sgibinish, Cajinish, Roisinish, Breinish, Griminish, Callernish, Liernish, Cairinish and in South Uist: Calternish, Gashernish, Geirinish, Hornish, Ornish, Usinish and Kearsinish. 'Aird', the Gaelic word meaning promontory in North Uist gives us: Aird nam Madadh; Aird an Runair; Aird Glas and in South Uist, Aird a'Mhachair; Ard Mhicheil and Aird Buidhe. Fraser shows influences of other Norse words such as 'Vik' (bay); 'Vatn' (water); 'A' (island) and 'Holmr' (islet) and Gaelic words such as Camas (bay); 'Sloc (pit) and 'Ob (inlet). Some of the habitative and topographic settlement names point to the particular customs of land use and tenure, for example the Norse word 'Saetr' meaning hill farm or sheiling, used in names such as Eashader on North Uist; 'Peighinn' the Gaelic for Pennyland, an old Scottish land measurement found in the West Highlands and believed to be of Norse origin; 'Gearraidh' the Gaelic word meaning enclosure (eg Hougharry, Tigharry, Grogary, Paiblesgarry, Reumsgarry all on N. Uist).

An extensive study of the placenames of Berneray was made by John Ferguson in 1983 and printed in 2008. Berneray is a small island (10.1 square kilometres) off the north coast of North Uist which it has been connected to by a road bridge since 1999. The population of Berneray was 138 (in 2011)."The name Berneray is generally accepted to be from 'ey', (island) and 'bjorn' (bear), Bjorn's Isle. The personal name Bjorn is common in Iceland." (Ferguson, 2015 p.3). There are two main townships, Ruisigearraidh and Borgh. Apart from them the Ordnance Survey (OS) map (1996) lists 22 placenames on Berneray. ${ }^{11}$ The later OS map (2007) adds fourteen more names to the $\operatorname{mix}^{12}$, (admittedly both these maps include other non-named features (shown as pictograms) such as cairn, chair stone, standing stone, etc. but nothing else is named). In contrast Ferguson's manuscript lists 206 separate names with explanations of their lineage and includes a sizable supplement listing names where the meaning or lineage is not so clear. Some of the descriptions are very detailed,

5. Tobar na leth-Pheighinn - well of the half-penny. This would probably be $1 / 24^{\text {th }}$ of a penny stirling (Scots) which in this case refers to the valuation of the land in the area known as the half-penny land. The well is in the shore a few years below the high tide mark. This is a natural issue of fresh water from which the Borve cattle drink freely. Tobar is the usual Gaelic name for well or spring of fresh water. N.B. - Gildbride

\footnotetext{
${ }^{9}$ The Place Names of Uist is part of a document consulted in the archive of the Kildonan Museum, South Uist in March 2015.

${ }^{10}$ http://www.ed.ac.uk/literatures-languages-cultures/celtic-scottish-studies/archives/archive-projects/place-namesurvey

${ }^{11}$ Rubha Bhiusnis, Rubha Mhànais, Rubh’ a’ Chorrain, Aird Ma-Ruibhe, Beinn Shleibhe, Beinn Ghainche, Màs a' Chapair (Màs a' Champair in 2007), Beasdaire, Cnoc Gunna, Cnoc, Bhuirgh, Loch Bhatersaidh (Loch Bhartarsaidh in 2007), Loch a Bhaigh, Loch Bhrusda, Loch, Beag Bhuirgh, Loch Bhuirgh, Port Ludaig, Poll an Oir, Bhaiteam, Eilean an Dùnain, Cràcanais, Brusda, Maol Bhàn.

${ }^{12}$ Cnoc nan Claigeann, Cnoc na Grèine, Sheabie, Rogh Lag na Muice, Taraloch , Loch nan Easgann, Knock Torla, Scalabriag, Baile, Beinn a'Chlaidh, Abhainn Cheap, Trealigarry, Rubha an Aoil.
} 
Morrison, the township smith, had a farthing land as a sub-tenant and the same amount for being the local smith. He lived in Seabaidh until he was driven out in the great sandstorm of 1697. The name of his Leth-Pheighinn has survived to the present day (Ferguson, 2008, p. 8).

As this quotation suggests all names exist in the same time zone regardless of whether the story or the people, who have given rise to the name, lived four centuries or four decades ago "Tobhta Uilleim - Tobhta, roofless walls and Uilleim, gen., of Uilleam G. for William. This was William MacMillan 1850-1929, Uilleam mac Aaisdair mhic Iain Bhàin." 13 (Ferguson, 2008, P 20). I will discuss later how, in a very similar way, my interviewees renamed parts of the Uists according to their experience. Many existing Berneray names describe a feature or an activity: what has been done, what can be grown, who can grow it or an event , "The popular adage, 'Every picture tells a story,' is very true; and if it were adhered to 'every place name tells a story' would be equally true" (Ferguson, 2008, p. 4). For example,

The sea around Berneray from the coast of Harris to the coast of Uist and the areas to the north and south of the island, contain hundreds of rocks, shoals and skerries, all with fascinating names, and all with their own story to tell. It is sad to admit that most of these are in dire danger of being completely forgotten, if their names and positions are not recorded now. For instance how many people today know why MacKillop Rock bears the name on Admiralty charts. Apparently this rock, which is situated one and a quarter miles north-north-westward of the western extremity of Vallay, North Uist, was uncharted when the Admiralty survey ship was doing revision in the area about 100 years ago. Due to his local knowledge, they had on board a John MacKillop from Berneray, a lobster fisherman who had gone to reside in Grimsay, North Uist. When John told them of a dangerous rock in the area they refused to believe him, and told him that the area had been accurately surveyed years ago. The out come was that John piloted the ship close to this non-existent rock, to the amazement of the officers who immediately baptized it MacKillop Rock. This is just on instance of how local knowledge was able to rectify a dangerous omission on an official chart (Ferguson, 2008, p. 4).

In the 1970s, Alec Maceachan's father was recorded talking about the placenames of Benbecula by Iain Stewart for the School of Scottish Studies. Alec gained his placename knowledge from him,

Even in the little gap there [looking at the map] where I stay, I could name you, from there to there, I could name you 20 different names for different headlands, and rocks and hillocks and points and bays and all the rest of it. These are not recorded on any maps and comes down to you know local tradition and ... I'm probably the only one that know that ... has that information now ... (Maceachan, recorded interview, 2015).

\footnotetext{
${ }^{13}$ Scottish Gaelic surnames are generally patronymic, i.e. they refer to a historical ancestor. The form of a surname varies according to whether its bearer is male or female.
} 
Placenames are the nodes or mental images for the cognitive map shared by the Gaelic speaking Hebridean islander. Scottish poet and novelist Iain Crichton Smith describes the centrality of Gaelic to Hebridean culture and place,

For, on the day I go home to the island and speak to my neighbor in English, it is not only the language that has died but in a sense the two who no longer speak it. ... I imagine those who lose their language dying in the same way as the language dies, spiritless, without pride ... One imagines the beggars of the spirit, no longer real people in a real place. They will be shadows cast by an imperialistic language that is not their own. For if they speak a language that is not their own they are slaves in the very centre of themselves. They will have been colonized completely at the centre of the spirit, they will be dead, exiles, not abroad but in their own land, which will not reflect back the names they have given it (Sinclair, 1996, p. 137).

Those who do not share the language cannot share the imaginary landscape, the meeting of past and present in the Gaelic placenames of their islands. Long ago linguistic anthropologist Sapir identified the unique realities shared by language groups,

Language is a guide to 'social reality' ... the 'real world' is to a large extent unconsciously built up on the language habits of the group. No two languages are ever sufficiently similar to be considered as representing the same social reality. The worlds in which different societies live are distinct worlds, not merely the same world with different labels attached (Sapir, 1929, pp. 68-69).

As the population of the Outer Hebrides decreases and, as more English-speaking incomers settle in the islands, there is a real sense of the importance of Gaelic and preservation of traditional culture. While many placenames are mapped, some are not. One of the traditional ways that the community passed down knowledge about of placenames was orally, through the medium of Gaelic, and through the tradition of the ceilidh.

\section{The ceilidh and the oral tradition}

Gregeen and MacKenzie writing about the Tiree ${ }^{14}$ bards $^{15}$ tell us that,

the most characteristic form of recreation was to meet in the "ceilidh-house' ${ }^{16}$ in the evening to pass the time in talk, story-telling and song. So much did song pervade life in the township that it appears to have been an essential as eating and sleeping (Sinclair, 1996, p. 83).

Hebridean writer Francis Thompson amplifies this,

\footnotetext{
${ }^{14}$ Tiree in a small inhabited island in the Inner Hebrides.

15 'Professional' poets and musicians previously found in Scotland, Ireland and Wales.

16 "One particular house was a favored as a meeting place and so was known as a ceilidh house.” (Stewart, 2005, p. 69).
} 
[I]n older times, the ceilidh was more important than just a gathering of neighbours to talk over local problems and discuss the import of whatever national news might have filtered through to the township via an itinerant packman or tinker. It was also the occasion when memories were revived, when the lineage of the folk of the town was re-stated, when the bards and singers were given the chance to freshen up old songs and poetry with yet another airing and when the young were gradually made aware of their responsibilities to their families and to the community at large; and, not least, when the older folk of the township were taken into the heart of the communal spirit as it was manifested by the ceilidh. Thus, the ceilidh had a definite social function in the crofting township, and was not the occasion for pure entertainment as it tends to be today (Sinclair, 1996, p. 87).

So the ceilidh helped to foster the intense sense of community expressed by many of my subjects "there were good ceilidhs in houses and there were pipers in Baleshare - four in one family - four good pipers ... you could go in any house without knocking" (MacDonald, recorded interview, 2015). It was also a conduit for the transmission of culture, history and social behavior, a place of speaking, singing and of listening and a place for "a continued remembered recreation of past stories" (Rose, 2003, p. 70).

The transmission of knowledge through the oral and the aural (the sounded and the heard) puts an emphasis on what anthropologist Steve Feld has termed acoustemology or "sound as a way of knowing" (1996) where knowledge is both transmitted and received through sound. This knowledge is specific to its means of transmission,

Sound ... [indicates] phenomena that function not as objects or subjects, as entities, but sound the temporal connections between objects and subjects as things thinging, contingently...We do not hear entities but relationships, the commingling of things which generate a sonic world, which we grasp ... by centering, decentering and recentring ourselves from moment to moment in the complex continuity of sound (Voegelin, 2014, p. 162).

Is it possible that in oral cultures where people where learn differently they also understand or 'sense' differently? Technocultural scholar Francis Dyson suggests that they do, in a way that negotiates the,

'unthought' and the unspoken, to develop other vocabularies and other forms of political, economic, and social organization. Sound's ephemeral and atmospheric nature is, like the environment, something that circulates outside of exchange, and refocuses attention on the space and the environment of the subject rather than the subject per se. The aural opens avenues toward an understanding that is arational, that evokes a grain (or rather tone) of thought and an aesthetics of listening that, I would argue, offers some entry into the dilemma of how to hear the world and in hearing, also be able to act, with the aim and existential condition of the 'in-common' (Dyson, 2014, p. 149).

In many oral societies the more abstract qualities of the sonic is used to help to convey meaning "In many African languages the pitch of speech sounds is an important feature, 
enabling much information to be conveyed using a set rhythm and tone" (Baddeley, 1999, p. 289). So not only is sound received and understood differently but oral cultures use sound differently in order to transmit knowledge.

For the crofting community the land holds individualized yet shared memories of place and function. In these 'performance spaces' past and present merge and placenames, particularly those in Gaelic, act as a mnemonic for dynamic memory re-creation which meshes the lived landscape. Traditionally the voice has been the medium for the transmission of memory and the way that it is used may convey meaning that, through the medium of sound and listening, is important for both 'knowing' and understanding.

\section{Mapping, placenaming and the Outer Hebrides}

The remote Outer Hebrides have long been the subject of curiosity whether from adventurous travellers (e.g. Martin, 1695; Walker, 1764-1771; Johnson, 1775; Boswell, $1785^{17}$ ) or early mapmakers ${ }^{18}$. Mapping renders a place according to the interest of the map-maker, "too often the act of 'seeing' $a s$ an embodied point of view is hidden and the fact that it is but one 'perspective' is, if not denied, at least not made explicit" (Heddon, 2008, p. 91). Mapping is also an act of power "a picture is a map when it is drawn by somebody with the power to draw maps" (Heddon, 2008, p. 92). In practice, mapping leads to a number of different results. Placenames become fixed by published maps, sometimes incorrectly, names can be misspelled or mis-translated,

The people that were recording these things on the map didn't have Gaelic, they just wrote it down as it sounded. It was how they heard it from the people. There were letters appearing that are not in the Gaelic alphabet (MacEachan, recorded interview, 2015b).

In this way, the process of mapping removes the lived experience of place from its inhabitants and fixes it for the perusal of others.

\section{Heritage and placename recovery}

Heritage recovery and recording is active in many parts of the Outer Hebrides. The heritage industry is driven by the recognition that a unique and precious society and culture is changing. ${ }^{19}$ Over the last few decades there have been numerous publications recording and re-telling the past (e.g. Hunter, 2000; Lawson, 2004; Sinclair, 1996; Stewart, 2005). This is not an entirely new phenomenon; oral historians and folksong collectors, including celebrated collectors such as such as John Lorne Campbell, Margaret Faye Shaw and Alan Lomax (who visited the islands in 1951), have been active for decades. ${ }^{20}$ Croft histories have also been painstakingly resurrected and published by Bill Lawson, prolific genealogist and historian of

\footnotetext{
${ }^{17}$ Included in Johnson and Boswell (1984).

${ }^{18}$ Early maps of the Outer Hebrides were made by Pont (1585), Blaeu (1654), Bold (1805, 1836), Ordinance Survey (1881, 1903). Many can be accessed via National Library of Scotland website: http://maps.nls.uk/index.html

${ }^{19}$ The total number of native speakers in the Scottish Gàidhealtachd is now around 58,000.

${ }^{20}$ Many of which are lodged at the School of Scottish Studies sound archive in Edinburgh.
} 
the Western Isles. There are local historical societies in many parts of the islands. Study of the local area and cross-generational learning is encouraged in the Scottish educational curriculum,

One of the topics through the 'Curriculum for Excellence (a new strategy for education in Scotland) is "My Local Area". If you have a teacher who's really interested in local heritage and local history they will then encourage the children to dig deeper into what they know about the local area and I think if it's done in that way they are able to make these links that make it relevant to them today. ... they want the children to learn in different way so they want them to learn out of the classroom as well as from members of the community (MacCuish, recorded interview, 2015a).

In recent times, there have been a number of projects to recover and record placenames by keen amateurs as well as the Scottish Place-Name Survey,

Even in the little gap there (looking at the map) where I stay, I could name you... from there to there, 20 different names for different headlands, and rocks and hillocks and points and bays and all the rest of it. These are not recorded on any maps and comes down to you know local tradition and ... I'm probably the only one that has that information now (MacEachan, recorded interview, 2015)

In the "public records of past events" (Rose, 2003, p. 363), placenames function as a symbol of the collective memory "inscribed in our biological and cultural inheritance" (Rose, 2003, p. 71). Recovering placenames shows both what is there and what has been deleted from maps, revealing a flattened landscape which negates the collective memories "which transcend the individual, welding together human societies by imposing shared understandings, interpretation ideologies" (Rose, 2003, p. 388). Thus official maps can materialize otherwise invisible power structures by revealing what can be commemorated on a landscape.

\section{Keeping it in sound: 'The Hebrides Suite: mapping the islands in sound'}

Since 1999, I have been examining the Hebrides through sound. More recently, I have extended my focus to think about the ways in which composed sound works can convey a landscape or lived environment. In 2015 my exhibition presented some of that compositional work alongside the new sound project which interrogated the resonances of, and intergenerational relationships to, placenames. In collaboration with Caitriona MacCuish, Museum Development Officer and Lisa Wilson, Heritage Officer from Museum nan Eilean, Benbecula I worked with pupils and staff from the Gaelic class at Sgoil Lionacleit, Benbecula, as well as members of the Comann Eachdraidh Uibhist a Tuath (North Uist Historical Society) and South Uist Historical Society. The project was supported by Museum nan Eilean, and University of the Arts London and resulted in 'Sandy Jaffas', a new composed sound work; a large wall piece (pic) which maps the Uists according to field recordings made, places mentioned in the interview and archive materials used in the compositions and maps made by each of the pupils. The exhibition 'The Hebrides Suite: Mapping the Islands in Sound' took place at the museum during 2015 and consisted of three, eight-channel sound works, the maps and items from the museum's collection relating to the history of recording sound in the Uists. 


\section{Fieldwork}

I made two trips to the Uists during 2015 researching placenames, maps and pictures and collecting recorded sound. During the first trip in March I listened to existing oral history material collected by the museum and historical societies. I also conducted interviews in English with seven older inhabitants of North and South Uist. On the second fieldwork trip, Caitriona, Lisa and I conducted interviews in English and Gaelic with the 15 pupils involved in the project. In between the visits the pupils themselves interviewed older members of their family or their community. The questions asked were simple and direct interrogating personal relationships to places. ${ }^{21}$

Time and time again, subjects of all ages revealed a strongly localized loyalty to their immediate area and the name of their township, spoken aloud, "I don't think there is a better place in the world than living in Sollas" (MacCuish, 2015), seemed to be so much more than a placename. Almost all subjects emphasized the importance of family, "I normally go to their house and have a nice chat with Granny" (MacVicar, 2015), particularly grandparents who seemed to play a central role in the family "sometimes go down to see where my grandparents lived when they were young" (Sheperd, 2015). The importance of community was emphasized with older subjects often hankering after former days when "you could go into anyone's house and most of them weren't even locked" (MacDonald, 2015c) but children's accounts still reveal a strong sense of community, "it's a good community hall and it's used really often" (MacCorquadale, 2015). In terms of favorite places, many subjects, particularly the younger ones mentioned the beach, "A wonderful place with beaches that go on for miles and miles" (Niclain, 2015), often that nearest their home ("there's a beach near where I live and the arctic terns come" (Sheperd, 2015). Other favourite places were the croft "especially in the spring because I like watching the lambs jumping about" (Beaton, 2015). There was a relatively wide understanding of histories of naming, "around here there is a name for every little hill, well and every little place. They already have their names from long ago" (Robertson, 2015) and an appreciation of the importance of knowing and preserving history and heritage: linguistic and environmental. Some more professional oral history subjects know a lot about names and history. A number of anecdotal commonly shared names that would not appear on a map emerged, "stinky Bay", "the turn", "Roddy's Road". From the forty or so people that were interviewed a picture emerged of a landscape traversed by memories, some big, some small, some a long time ago, some more recently - of falls, or funny things, of small disasters and of big moments in history. Few of these are commemorated on the landscape and in the course of the interviews new names were suggested. Sandy Jaffas is one of these "It's called Sandy Jaffas because my friend took a pack of jaffa cakes here and he dropped some on the sand" (Beaton, 2015).

While collecting material and aware of the compositional task ahead, I was listening out for specific tones of voice, textures, sound bites or musicality and, I was aware that long sentence and long stories are generally difficult to use. When however I came to think about structuring the work I started to appreciate the revelatory quality of the spoken placenames,

\footnotetext{
${ }^{21}$ These questions were: Do you have a favourite place? Is there a place that has special memories for you? Have you got a funny or sad memory of a place? Are there any places that were special to your parents or your grandparents? Is there anything you can tell me about the placenames in the area? Do you know how any of them got their names? Are there any places where you know of something that happened that is not recorded in the name? Where do you live? Where did your family live?
} 
the timbre and lilt of the voice as it intones those words, as if the embodied subjectivity of the speaker imbues the silent map with new powers revealing the true nature of the names and what they mean. In common with travel writer Robert Macfarlane talking about anthropologist Basso's research in Arizona and his own in Lewis, I felt that,

language is used not only to navigate but also to charm the land. Words act as compass; place-speech serves literally to en-chant the land: to sing it back into being, and to sing one's being back into it (MacFarlane, 2015, p. 22).

The composition of 'Sandy Jaffas' 22 is driven by this place-speech. The repeating placenames, spoken by a number of subjects, enters us through the ears and penetrates our head resonating like an anchor or a mantra,

$$
\begin{aligned}
& \text { Baleshare - Baleshare } \\
& \text { Baleshare - Baleshare (Lane, 2015) }
\end{aligned}
$$

To me, the spoken placenames sound as if they carry a common sense of Dyson's 'incommon', as if they are the outward manifestation of interiorized sonic landscapes, meshing past, present, ideas of kinship, place, landscape feature overlaid with the shared and personal experiences of each speaker and each listener. In this way using those voices in the work could be said to reveal, through sound, where the self is the sound of each recorded voice. Furthermore it reveals the "relational status of the 'self': the 'self' not only a historical and cultural construct but (is) imbued with and indeed is inseparable from, others" (Heddon, 2008, p. 124). Obviously each 'self' that is revealed is mediated by me, as the composer and I have responsibility for those representations. My aim is to transmit, through recorded sound, the stories and realities of others meshed with my own understandings and subjectivity. Rather than expropriating someone else's story I am placing the actual recorded voice within a composition, literally giving each voice an individual place and a place in the sonic community of the work.

\section{Conclusion}

There is a fundamental difference between the flat mapped place-names and the same names spoken between Hebrideans. Just as "Plato describes Socrates as claiming that writing is inhuman in that it pretends to establish outside the mind what in reality can only be in the mind " (Rose, 2003, p. 72), the 'sounding' of those names and what happens in the spoken oral/aural exchange between two or more people is in the mind. For Lippard (1997, p. 10), place is a lived-in landscape, a "space combined with memory" and the place and the lives are inseparable. "Place is not something that simply exists, but is rather something that we bring into existence through our relationships with it and our relationships with other in, on or around it" (Heddon, 2008, p. 93),

Reading 'The Onomasticon', on you realize that Gaelic speakers of this landscape inhabited a terrain which is, in Proust's phrase, 'magnificently surcharged with names'. For centuries these place-names have spilled their poetry into every day Hebridean life.

\footnotetext{
${ }^{22}$ https://hebrides-suite.co.uk/works-2/sandy-jaffas/
} 
They have anthologized local history, anecdotes and myth, binding story to place. They have been functional - operating as territory markers and ownership designators - and they have also served as navigational aids. Until well into the twentieth century, most inhabitants of the Western Isles did not use conventional paper maps, but relied instead on memory maps, learnt on the land and carried on the skull. These memory maps were facilitated by first-hand experience and were also, as Finley puts it, 'lit by the mnemonics of words' (MacFarlane, 2015, p. 20).

When a placename is spoken between inhabitants of the Outer Hebrides it comes already meshed within an intangible cultural heritage and forms a network through which memory is transmitted, received, re-imagined and shared,

Conversation must be understood as it is said or written - or better still practiced ... as the set of conversions and frequent repetitions of the bodily, verbal and theoretical repositionings of its participants (Serres, 1985, p. 331).

In the autotonomic exchange sound is "a sculptural material to explore the complex relationships between body, voice, sound and subject" (Lane 2008, p. 161) and the space of the sonic exchange reinforces history and personal and collective experience and allows people to co- create a past and a present. It is a dynamic sound space in which the mnemotechnic training of memory (Rose, 2003, p. 72) is iterated, and it contrasts sharply to the imposed order and power relations of the map. A composed sound work which uses recordings of place-speech, or verbal mnemonics, has the potential to bring these memory records alive. In contrast, a video or audiotape, a written record, do more than just reinforce memory: they freeze it, and in imposing a fixed linear sequence upon it, they simultaneously preserve and prevent it from evolving and transforming itself with time and allows dynamic new relationships to form through the co-creation of more and different pasts and presents (Rose, 2003, p. 70). The various soundings of the placenames of the Outer Hebrides give access to the unique "deep maps', meaning the 'accumulation of narratives " that adhere to sites" (Heddon, 2008, p. 100) and speaking them aloud renders them as a spell or incantation full of people, individual lives, communal history, story, song, place, identity and home. Through the heritage projects, schools and projects such as 'mapping the islands in sound', the people of the Hebrides constantly reimagine the 'map' - fluid, fractured, contested, layered, and mixed up: a space of social practices. It is performed and re-performed with every story, with every local history project, with every visit to a grandparent. Each place and each placename is contingent on time and event. The placenames of the Uists and the other Outer Hebridean islands are not only unique but they have a particular role as a living part of a shared language, history and culture. As anthropologist Wade Davis has said "Every language is an old-growth forest of the mind," 23 and within the Gaelic of the Outer Hebrides every placename is a dynamic mnemonic for a complex web of shared and individual memories.

\footnotetext{
${ }^{23}$ Wade Davies, TED talk (2003). Retrieved from http://www.ted.com/talks/wade_davis_on_endangered_cultures/transcript?language=en
} 


\section{References}

Baddeley, A. (1999). Essentials of human memory. East Sussex: Psychology Press.

Chatwin, B. (1987). The songlines. London: Vintage.

Cooper, D. (1979). Road to the Isles: Travellers in the Hebrides 1770-1914. Glasgow: Drew Publishing.

Dean, T. \& Deller, J. (2005). Place. London: Thames and Hudson.

Dyson, F. (2014). The tone of our times: Sound, sense, economy and ecology. Cambridge MA: MIT Press.

Feld, S. (1996). Waterfalls of song: an acoustemology of place resounding in Bosavi, Papua New Guinea. In S. Feld \& K. H. Basso (Eds.), Senses of place (pp. 91-135). Santa Fe NM: School of American Research Press.

Ferguson, J. (2008) The place names of Berneray. Isle of Skye: Strath Press. Heddon, D. (2008). Autobiography and performance. Hampshire: Palgrave.

Hunter, J. (2000). The making of the crofting community. Edinburgh: Birlinn.

Lawson, B. (2004). North Uist in history and legend. Edinburgh: John Donal Publishers.

Johnson, S., and Boswell, J. (1984). A journey to the Western Islands of Scotland and the journal of a tour to the Hebrides. London: Penguin

Lane, C. (2006). Voices from the past: compositional approaches to using recorded speech. Organised Sound, 11(1), 3-11.

Lane, C. (2011). Listening for the past: a composer's ear-lead approach to exploring island culture past and present in the Outer Hebrides. Shima: International Journal of Island Cultures, 5(1), 114-127.

Lane, C. (2013) The Hebrides Suite. Frankfurt, Germany: Gruenrekorder, CD.

Lane, C. (2015) Sandy Jaffas. Audio Recording.

Lane, C., and Carlyle, A. (2013). In the field: The art of field recording. Axminster: Uniformbooks.

Lippard, L. (1997). The lure of the local: Senses of place in a multicentred society. New York: New Press.

MacFarlane, R. (2015). Landmarks. London: Hamish Hamilton.

MacKinnon, K. (1977). Language, education and social processes in a Gaelic community. London: Routledge and Kegan Paul

Martin, M. (2014). A description of the Western Islands of Scotland circa 1695. Edinburgh: Birlinn.

Ordnance Survey (1996.) Sound of Harris and St Kilda. Landranger Map, Southampton: Ordnance Survey

Ordnance Survey (2007). North Uist and Berneray/Uibhist a Tuath agus Beàrnaraigh, Explorer Map. Southampton,: Ordnance Survey

Rose, S. (2003). The making of memory. London: Vintage.

Sapir, E. (1929). The status of linguistics as a science. Language, 5(4), 207-214.

Serres, M. (1985). The five senses. London: Continuum

Shaw, M. F. (2008). From the Alleghenies to the Hebrides: An autobiography. Edinburgh: Birlinn.

Sinclair, M. (Ed.) (1996). Hebridean odyssey songs: Prose and pictures from the Hebrides of Scotland. Edinburgh: Polygon.

Spirn, A.W. (2008). The language of landscape. New Haven MA: Yale University Press. 
Stewart, K. (2005). Crofts and crofting. Edinburgh: Mercatpress.

Szwed, J. (2011). The Man who recorded the World: A biography of Alan Lomax. London: Arrow

Walker, J. (2010). An economical history of the Hebrides and Highlands of Scotland V2 (1808). Whitefish MT: Kessinger.

Voegelin, S. (2014). Sonic possible worlds: Hearing the continuum of sound. London: Bloomsbury.

Yates, F.A. (1992). The art of memory. London: Pimlico.

\section{Recorded Interviews}

Beaton, Calum (2015). Lionacleit, Benbecula. Interviewed by Lisa Wilson.

MacCorquadale, Marion (2015). Lionacleit, Benbecula. In person.

MacCuish, Chrissie (2015). Lochmaddy, North Uist. In person.

MacCuish, Caitriona (2015a). Lionacleit, Benbecula. In person.

MacDonald, Maggie Flora (2015). Lochmaddy, North Uist. In person.

MacDonald, Jane (2015c). Lochmaddy, North Uist. In person.

MacEachan, Alastair (2015). Lionacleit, Benbecula. In person.

MacEachan, Alasdair, Catriona Garbutt, and Jean MacEachan (2015b). Interviewed by Ceitidh MacLennan and Fiona MacDonald, Lionacleit, Benbecula. Translated from Gaelic by Lisa Wilson.

MacKillop, Isa (2015). Lochmaddy, North Uist. In person.

MacVicar, Amber (2015). Lionacleit, Benbecula. Interviewed by Lisa Wilson.

Niclain, Peigi (2015). Middlequarter, North Uist. Interviewed by Anna Niclain.

Robertson, Uisdean (2015). Caranish, North Uist. Interviewed by Rachel Maclean.

Sheperd, Ben (2015). Lionacleit, Benbecula. In person. 